\title{
View of the Confederation of Swedish Enterprise
}

\author{
Lars Gellner
}

I. The Rüffert ruling

II. The Laval ruling

\section{The Rüffert ruling}

Professor Bruun thinks the ECJ's interpretation of the Posting Directive in the Rüffert case is astonishing. The reason is that, according to the ECJ's interpretation, the Directive is in conflict with ILO Convention No 94.

I cannot understand this reaction. A possible conflict between EU legislation and agreements that Member States have made is not an unanticipated situation. It is foreseen in the Treaty, article 307. And that article establishes the fact that a Member State that has produced an agreement in conflict with the Treaty must make efforts to remove elements in conflict with the Treaty.

The $97^{\text {th }}$ ILO-session in Geneva in June this year was - among other things - about the issue of integrating labour clauses into public procurement contracts. According to the provisional record from the session the basic assumption by the Committee of Experts seemed to be that competition on the basis of labour costs is socially unhealthy and should always be avoided.

When we talk about public procurement contracts it is important to evaluate whether or not competition eliminates corruption, increases productivity and transparency and procures goods and services at the best value for money or best quality for the price.

In my opinion these are important factors to be considered.

There is a number of concerns related to the Convention. There are about 60 countries that have ratified the Convention, but only one quarter of them are actually applying it. The Committee of Experts in the ILO-session has noted that Member States of ILO are unwilling to take the necessary action to implement the Convention. One conclusion is that the principle that the State should act as a model employer by offering the 
most advantageous conditions to workers paid indirectly through public funds does not seem to be popular.

Furthermore the prevailing view of governments is that workers employed under procurement contracts are not in need of special protection over and above national labour and employment laws. The idea of including labour clauses in public contracts is not widely accepted among Member States of ILO.

Against this background perhaps the Rüffert ruling is not very alarming.

\section{The Laval ruling}

In Sweden the ruling in the Laval case has led to a widespread debate regarding trade union rights. From trade unions and some politicians on the left wing there have been claims to change the Swedish legislation in order to guarantee that the system with collective agreements can be used against foreign EU-employers. Efforts are even made by trade unions to postpone Sweden's approval of the Lisbon Treaty due to the consequences of the Laval ruling.

Maybe a solution including collective agreement is good. The alternative is, roughly speaking, minimum pay determined by the legislator, directly or indirectly. The Confederation of Swedish Enterprise has not yet made a choice what solution to promote.

However, there is one legal problem with the collective agreement-solution. According to Swedish labour law there is no guarantee, in my opinion, that the foreign employees will get the pay regulated by the agreement. They are not members of the Swedish trade union that is part of the collective agreement and their employment contracts will not be filled out by a collective agreement at the workplace - because there is no such agreement at the workplace.

As the Rüffert ruling establishes, it is not enough if a Member State in the national Posting of Workers legislation only refers to a collective agreement for setting the pay. It is, in other words, not allowed to in blank delegate the establishing of pay to the social partners at the national level. This is not a legislation in accordance with article 3.1, first paragraph.

There are drawbacks also with the legislator-solution as well. I do admit that letting a question of setting wages be solved by politicians is not the common way in Sweden. It must however be considered that we do not have a tradition of regulating wages for foreign employees.

Let me finish by declaring that Sweden and other states have joined the EU because they think that a membership best promotes economic development and increased welfare. The freedom to provide services is one of the fundamental principles of the Community and therefore one of great importance for employers all over Europe. It would have been remarkable if ECJ should not have defended that principle. 